\title{
The Safety and Hygiene at Work in a School Curriculum
}

\section{Katarína Ižová*}

\begin{abstract}
The article discusses the implementation of safety, hygiene and health measures at work into the education at all levels - from preschools to university education. It is focused on the purposeful and systematic shaping and developing the knowledge and expertise in OSH (Occupational safety and health) from an early age, because this issue is under current legislation concerning teaching.
\end{abstract}

Key words: health and safety at work, education, sectional theme.

\section{Introduction}

The education in occupational safety and health at work is a process designed to purposeful and systematic creation and development of knowledge, skills, habits, awareness, attitudes and desirable forms of behavior of employers and employees. The current Law no. 140/2008 concerns the issue of teaching subject at schools preparing students for future profession and continuing adult education including retraining. From an institutional aspect, this process begins at preschool and continues at all levels of education and vocational training to implement the economic practice and involve the domain of edification adequately.

\section{Rome Declaration on Mainstreaming OSH into education and training}

The main objective of the Rome Declaration, which was realized on the 1st to the 3rd October 2003 during the Italian Presidency, is to prepare and sustain people during their life, since their childhood, engaging schools and any other professional training institution, in actions providing safer and healthier workforce in the EU of tomorrow. Experts agreed upon the need for the European strategy based on qualified and quantified goals aimed at preparing children and young people for future work life. The health and safety experts agreed upon the need for the European strategy based on qualified and quantified goals aiming at:

- providing all citizens and workers, in particular, with a life long learning;

\footnotetext{
* Katarína Ižová, Dubnica Technological Institute. Dubnica nad Váhom, Slovakia; katka.izova@gmail.com
} 
- improving the involvement of initial and continuing educational and training system in fostering health and safety in the workplace;

- preparing children and young people for the challenge of their future working life providing occupational safety and health.

\section{Occupational safety and health at work in education}

One of the main objectives of the concept of state policy OSH is to build an effective system of education to health and safety from the basic to academic education including the training of employees and certification of specialized forms of education. Establishing an effective system of education to health and safety requires an all school approach, because only then we can ensure a safe learning environment for students as well as health and safety of the school staff. Capabilities of OSH principles and the educational process at each stage are different (The conception of OSH state policy).

The realization program of conception OSH in 2012 (The conception of OSH state policy) imposes to ensure the development of the school system of education to OSH and quality of education in preschools, elementary schools, secondary schools and universities, continuing education and teacher training for education to OSH. Within the measures and tasks that are set to reduce the number of accidents at work in our republic according to the concept of the state OSH policy, the introduction of teaching chapters from the OSH into the training of students at secondary schools and universities with an emphasis on identifying and managing risks in concrete terms including the prevention are included (The conception of OSH state policy).

\section{A) Preschools}

The objective of preschool education on safe conduct and behavior is the formation of a positive relationship to the children's life protection, their health and the health of other people. According to the State education program for preschool education (The state education program ISCED 0) in cognitive area within the thematic area children should:

- differentiate simple and intuitive way to describe the health status and illness,

- observe the principles of health with the help of adults,

- adopt positive attitudes to their health and the others' health and describe them through various artistic means of expression,

- summon adult assistance in emergency situations, which is at risk of health or the health of others, be aware of a risk of the contact with strangers (refuse candy from strangers, see it as a health hazard), 


\section{Acta Technologica Dubnicae}

volume 1, 2011, issue 2

- identify the causes of potential danger and harm to disable handling with certain subjects, for example sharp objects, matches, medicines, chemicals, detergents, electrical appliances, but also of the unknown nature,

- recognize, differentiate, select and choose healthy food.

The issue of ensuring the safety and health is also an integral part of the content of education of children in kindergartens. The children are taught through the content to protect their health and the health of the others and to deal with rudimentary healththreatening situations (The state education program ISCED 0 - preprimary education).

Many kindergartens are involved in the healthy kindergarten project which is a part of the project "School supporting health". The aim is to create conditions for the correct psychical, physical, social and emotional development of pre-school age children by applying educational principles and creating a favorable learning environment. There are also other health lifestyle programs for kindergartens, such as "Strengthening physical and psychological health of children of pre-school age", "Step by step", "Golden apple", and "We want to breathe fresh air".

\section{B) Elementary schools}

The sectional theme "The life and health protection" in the elementary school curriculum is implemented through the State education program and separate organizational forms of teaching - didactic games. The aim is to form pupil's relationship to the protection of their health and life and also health and life of other people, to provide students with necessary theoretical knowledge and practical experience, to acquire knowledge and skills in self-protection, assistance to other health threats and life (The state education program ISCED 1, ISCED 2).

\section{C) High schools}

The compulsory part of education for pupils of secondary vocational schools in the Slovak republic is a subject matter of "Protecting life and health". The content of the curriculum is implemented by two separate exercises and special purpose courses for the protection of life and health. The curriculum acquaints students with the basic obligations of workers, manufacturing, marketing, distribution centers and service centers by profiling graduate. The content of the curriculum also introduces them to the device manufacturing, marketing, distribution centers and the center of services for profiling. It teaches the occupational health and informs them about the most common sources and causes of accidents. Students learn the basis of first aid in accidents. The content of the curriculum also introduces hygiene standards, personal hygiene and workplace to them, familiarizes them with the operating unit, equipment manufacturing, sales, distribution and service centers and personnel. The curriculum acquaints students with basic obligations of the whole staff. 


\section{Acta Technologica Dubnicae}

volume 1, 2011, issue 2

The sectional theme is realized through the subject of the State educational program and separate organizational forms of teaching - special exercises and the course "The life and health protection" (The state education program ISCED 3, 3A). It integrates the capabilities of students aimed at protecting life and health in emergency situations, also during the stay and movement in nature, which may arise from unforeseen threats of the surroundings.

The objective is:

- to form the relationship of students to the issue of their health and life, also health and life of other people,

- to provide the student with necessary theoretical and practical knowledge, to acquire knowledge and skills in self-protecting and providing assistance to others in case of threats to health and life,

- to develop the moral character of students which is the basis of national and patriotic feeling,

- to form the conditions for achieving higher fitness, and organism resilient to physical and psychological burdens of difficult life situations.

For secondary vocational schools the education to health and safety, hygiene work and fire protection are an integral part of the theoretical instruction and practical training (The state education program ISCED 2B, ISCED 3, ISCED 3A). In the opinion of several experts, while there are some excellent resources available for teachers, much less attention has been paid to the training of teachers. It is recognized that teachers need training in delivering risk education; if they do not have such training, and risk education is just one option on the curriculum to choose from, they may be reluctant to teach it and opt for topics they feel more comfortable with, even if they have been provided with good resources.

\section{D) Universities}

The issue of safety and health at work penetrates into the education at universities and colleges. The common principles of work safety should be incorporated into the curriculum of education at universities and colleges. The students must be oriented in this field, because they are future employers and employees in various positions.

The specificity of OSH future occupation is incorporated into appropriate vocational training taking the study program into account. It should be noted that the graduates of university education shall be employed at different levels of management functions of production entities, sites and services according to their erudition in OSH management. 
The universities and colleges included in OSH training:

- Slovak University of Technology in Bratislava

- Faculty of Material Sciences and Technology in Trnava

- Technical University of Košice

- Faculty of Mining, Ecology, Process Control and Geotechnologies

- Faculty of Mechanical Engineering

- Faculty of Manufacturing Technologies

- Constantine the Philosopher University in Nitra

- Faculty of Education

- Faculty of Social Sciences and Health Care

\section{Conclusions}

The education and training to health and safety in the school system requires ILO Convention no. 155. Currently in the Slovak Republic, OSH law regulates the area of health and safety and risk prevention. This issue must be the subject of teaching at school preparing students for profession and continuing adult education including retraining. The improvement of safety and health at work has significant economic importance, because it provides optimized workflow, increases the confidence of employees, reduces losses and provides higher productivity, efficiency, quality of work, and increases the prosperity of business and society. It is necessary to introduce this issue into the school curricula and to prepare students for safety at work.

\section{References}

Rome Declaration on Mainstreaming OSH into education and training. Retrieved 20. 8. 2011 from <http://osha.europa.eu/en/topics/osheducation>

The conception of state policy OSH. Retrieved 7. 8. 2011 from <http://www.employment.gov.sk/pk/1380_2002_III_11/vlastnymat.rtf>

The state education program ISCED 0. Retrieved 10. 8. 2011 from <http://www.statpedu.sk/sk/Statny-vzdelavaci-program.alej>

The state education program ISCED 1. Retrieved 10. 8. 2011 from <http://www.statpedu.sk/sk/Statny-vzdelavaci-program.alej>

The state education program ISCED 2. Retrieved 10. 8. 2011 from <http://www.statpedu.sk/sk/Statny-vzdelavaci-program.alej>

The state education program ISCED 2B. Retrieved 10. 8. 2011 from <http://www.statpedu.sk/sk/Statny-vzdelavaci-program.alej>

The state education program ISCED 3. Retrieved 10. 8. 2011 from <http://www.statpedu.sk/sk/Statny-vzdelavaci-program.alej>

The state education program ISCED 3A. Retrieved 10. 8. 2011 from <http://www.statpedu.sk/sk/Statny-vzdelavaci-program.alej> 